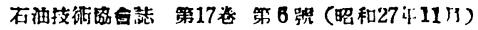

JOURNAL OF THE JAPANESE ASSOCIATION OF PETROLEUM TECHNOLOGISTS VOL. 17. NO. 6 (Nov., 1952)

\title{
酒田沛附近の天然ガス及び その利用價优について
}

舟越宣*

（炤和27年 8 月 30 日受理）

\section{On the Natural Gas Produced Adjacent to Sakata City and its Utilities.}

by Ryu FUNAKOSHI

The auther investigated the exploration wells of natural gas which were drilled in Sakata City recently. And he found that, there are 4 strata of natural gas within $100 \mathrm{~m}$ in depth which prodvce $200 \mathrm{~m}^{3}$ per day, and a hopeful stratum within $200 \mathrm{~m}-250 \mathrm{~m}$ too. By this fact, he concluded one can utilize these gases to supply to Sakata City as the town gas availably.

\section{I . 序言}

酒田市附近は日本でも有数な天然ガスの徵候地であつて，これが调甭の目的として は,すでにC式 6 琌・R式 1 坑が掘鳘せられているが，未だに事業として発展してお らない。

天然ガスの利用方法は臽々あるが，酒田市には都市ガスがない。天然ガスを開発し て甫民に給する事業も考えられるので，既掘井で得た資料を検傠した上で，都市ガス として利用することについて見船を述べて見る。

\section{II沿革及び現況}

生内平野一带に天然ガスの存在することは古くより知られ，河川中あるいは用水路

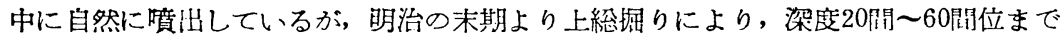

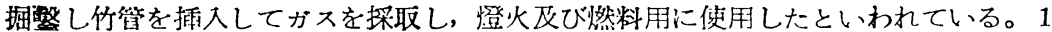
坑当り多いものは 100 立方尺/日〜500 立方尺/日の自噴ガス老採取したとのことであ るが，工業用としては極く僅かを試釱辤のパーナーに使用していたに過ぎない。

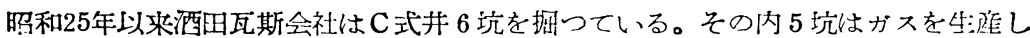
ている。従つてガス量は調查し得た。しかしガス層の正確なる梁度は明䐲でなかつた。

しかし酒田市は昭和 25 年に政不並びに山形祡の助成金を得て， R式 1 号井老据警 した。梁度 $400 \mathrm{~m}$ まで掘つて電探を实施した。その結朵としてC式井では判然にしなか

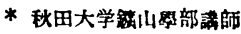




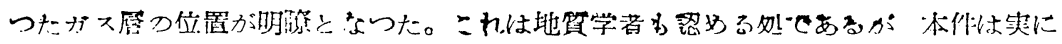

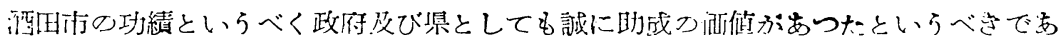

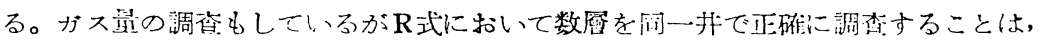

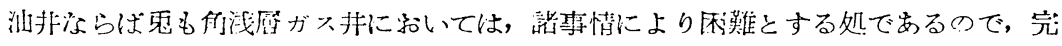

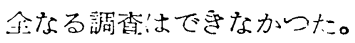

帝不は炤和21年に市の北隅に深度 $1,100 \mathrm{~m}$ 井を抱篮している。瓦斯の調查の目的で はないが，雷探を实施したのでガス厤の対比ができて，天然ガスの調查に大いに参荀 になつている。

\section{III . 最近掘擎せられた各井の概況}

\section{C式井}

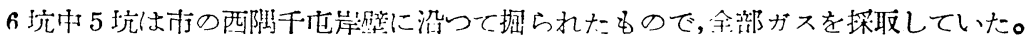

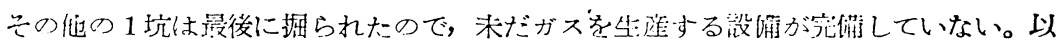
下各州について略記する。

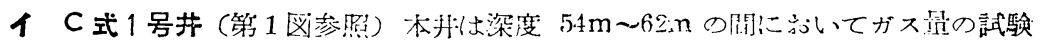

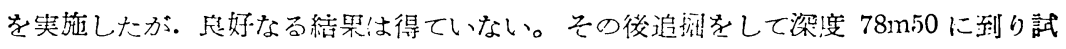
跧の結果, ガス望 $130 \mathrm{~m}^{3} /$., 水 $380 \mathrm{~m}^{3} / \mathrm{d}$ であつた。しかるに砂の押し出しが多くて

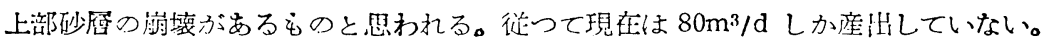

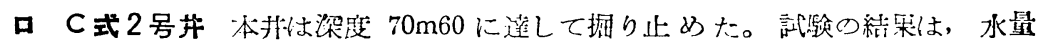
$760 \mathrm{~m}^{3} / \mathrm{d}$ に対して，ガス星 $130 \mathrm{~m}^{3} / \mathrm{d}$ であるが，孔明管が不充份であるから，ガンパ 一を実施し埋没孝腹桜することにより，ガスは增望するものと㮣われる。

八C式 3号井 本井は大体において篎全なる坑井と思われる。仕上げは $61 / 2$ G.C.P. の悄泎水であつて, 孔明管は $1 / 8^{\prime \prime}$ 丸穴, ビッチ $2^{\prime \prime}, 6$ 列とした。試験の

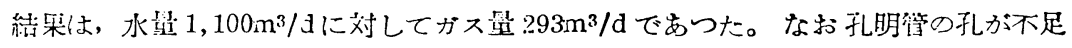
であるので, 63m〜 71m50の間をガンパーした。その試験の結果は, 水盖 $800 \mathrm{~m}^{3} / \mathrm{d}$ に

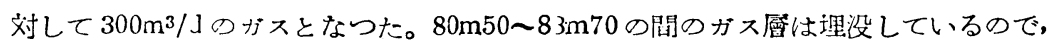
ガスは汕ていないものと思う。

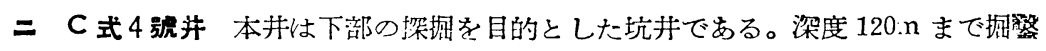

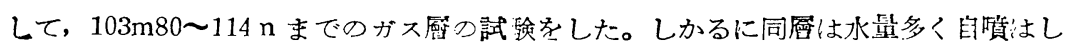

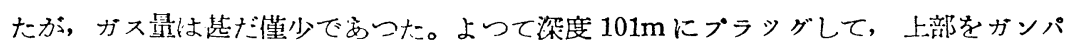

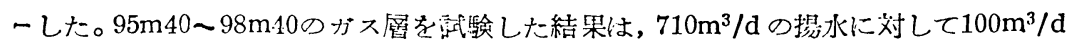
のガス量であつた。セメントを使用しないガンパーであるので, ガス水比 $1: 7$ であ る。他屬の水が涯入していると思われる。

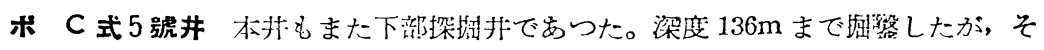
の結果は $100 \mathrm{~m}$ 以下には造好なガス罚はないことが判明した。よつて $10 \mathrm{~m}$ 附近にプ

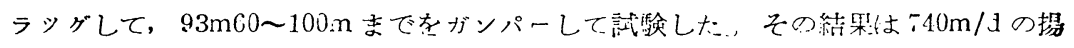

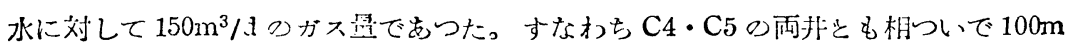




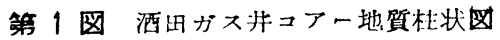

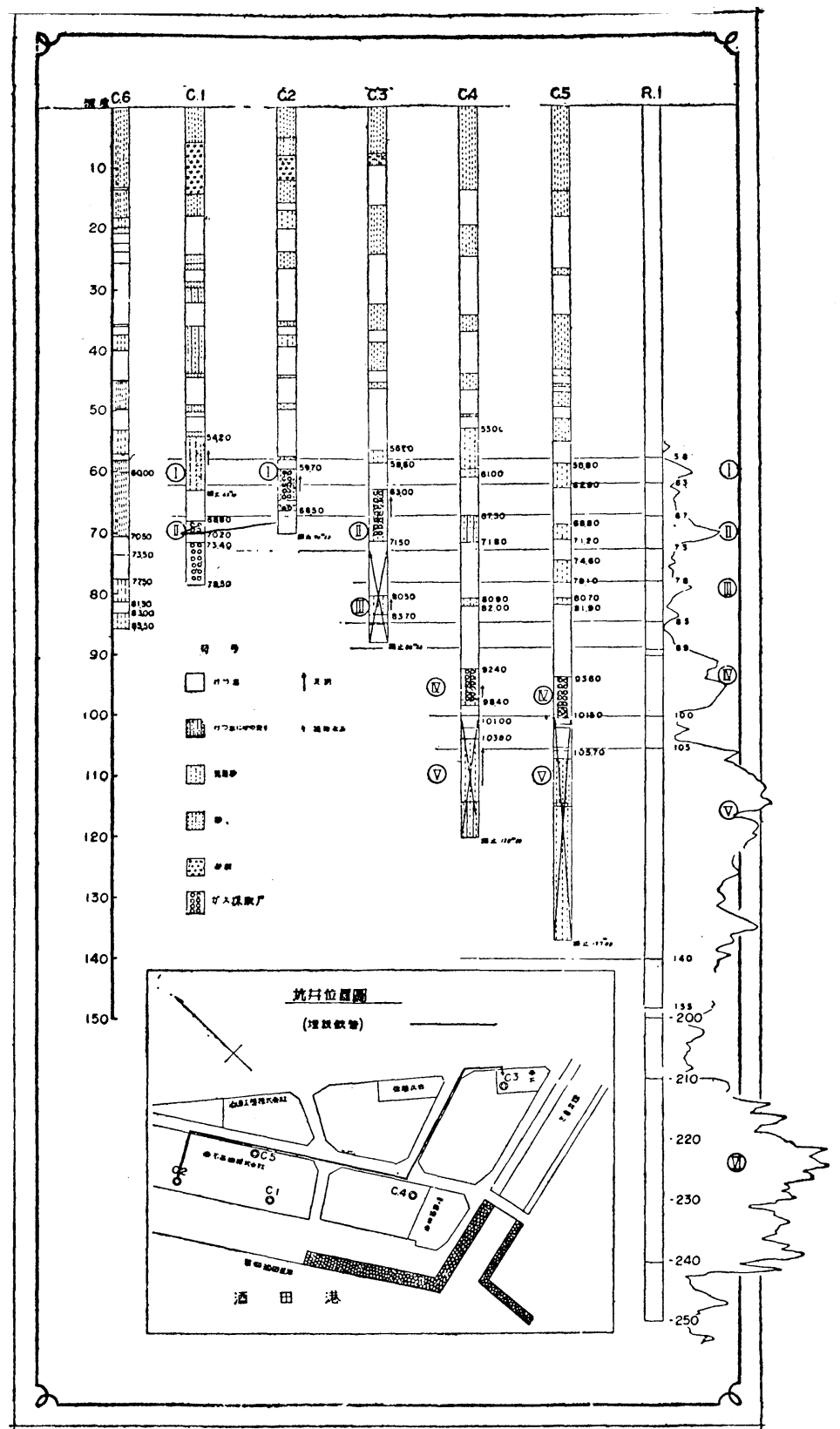




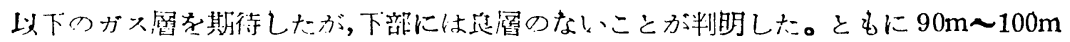
の将索採取している。

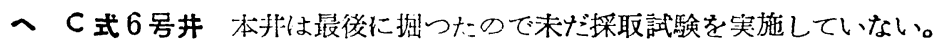

2. 瓦斯の性質

各售別の瓦斯の分析は行つていないが，C2号井のものの分析の結果は，次の通り

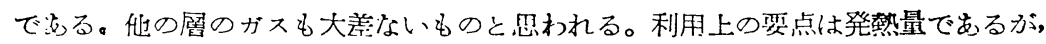
これは主とし $\mathrm{CO}_{2}$ の含有昷によつて左右せられる。

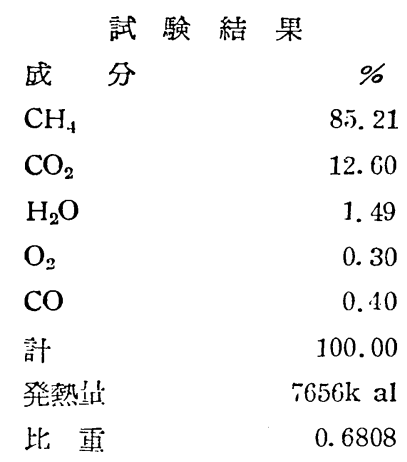

この分析の紪果る見るに， $\mathrm{CO}_{2}$ が $12.6 \%$ 念有せられていることが注目すべきであ

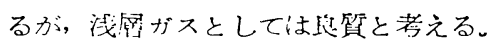

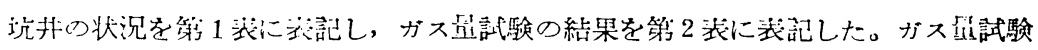

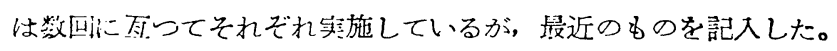

第 1 表 C式坑浩の状況

\begin{tabular}{|c|c|c|c|c|c|c|c|}
\hline 坑非名 & 開抗日 & 完成日 & 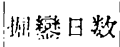 & 坑 径 & 深 度 & 正晸廍 & 備 \\
\hline C 1 & $\begin{array}{l}25.4 .26 \\
25.7 .31 \\
26.3 .25\end{array}$ & \}$^{26.4 .30}$ & 判 3 力月 & $\begin{array}{l}5^{\prime \prime 5} / 8 \\
4^{\prime \prime 1} / 2\end{array}$ & $\begin{array}{c}\mathrm{m} \\
78.50\end{array}$ & $\begin{array}{c}\mathrm{m} \\
\left(\begin{array}{c}68.80 \\
78.50\end{array}\right)\end{array}$ & 艎り下げて戌功 \\
\hline C 2 & 25.5 .25 & 25.10 .1 & 8 日 & $\begin{array}{c}6^{\prime \prime 1} / 2 \\
\text { 中間水 } 15 .\end{array}$ & 70.60 & $\left(\begin{array}{l}59.70 \\
66.50\end{array}\right)$ & 孔明管の分不足 \\
\hline C 3 & $25.6 \cdot 20$ & 25.10 .1 & 10日 & 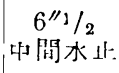 & 88.30 & $\left(\begin{array}{l}63.00 \\
71.50\end{array}\right)$ & $\begin{array}{l}\text { ガソパーにて成 } \\
\text { 功 }\end{array}$ \\
\hline C 4 & 25.8 .10 & 26.4 .17 & 13日 & $5^{\prime \prime 1} / 2$ & 120.00 & $\left(\begin{array}{l}92.40 \\
98.40\end{array}\right)$ & 闰上 \\
\hline C 5 & $25.10 .26 \mid$ & 26. ?. 17 & 63 日 & $6^{\prime \prime 1} / 2$ & 136.00 & $\left(\begin{array}{r}93.60 \\
101.50\end{array}\right)$ & 蔺上 \\
\hline
\end{tabular}

3. C式找掘鳌の結果について

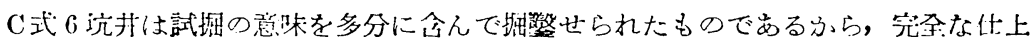




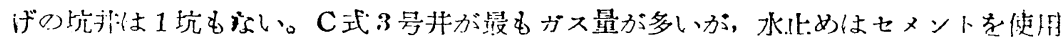

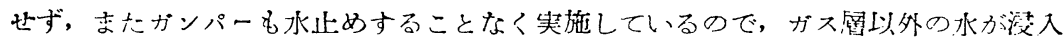
しているものと思わ机。徉つて各井とも充分なる能力を発揮していない。今㷋の浣

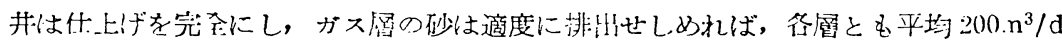

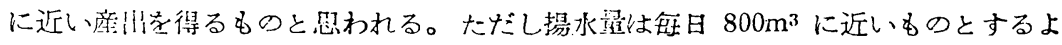
らにコンプレッサーを栖四しなければならない。

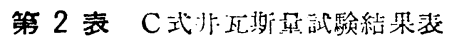

\begin{tabular}{|c|c|c|c|c|c|c|c|c|}
\hline 抗朴名 & 洲定日 & $\begin{array}{c}\text { リフト早 } \\
\text { イプ深传 } \\
\mathrm{M}\end{array}$ & 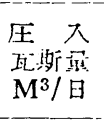 & $\begin{array}{l}\text { 棇出是 } \\
\mathrm{M}^{3} / \text { 日 }\end{array}$ & $\begin{array}{l}\text { 採收 } \\
\text { 㞷断量 } \\
\mathrm{M}^{3} / \text { 日 }\end{array}$ & $\begin{array}{l}\text { 掦水点 } \\
\mathrm{M}^{3} \text { 昌 }\end{array}$ & 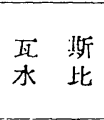 & 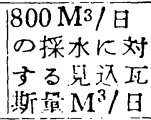 \\
\hline C 1 & $\begin{array}{l}26.4 .30 \\
27.4 .10\end{array}$ & $1^{\prime \prime} \times 47 \mathrm{~m}$ & 430 & 510 & $\begin{array}{r}130 \\
80\end{array}$ & $\begin{array}{l}380 \\
300\end{array}$ & $\begin{array}{l}1: 2.8 \\
1: 3.7\end{array}$ & $\begin{array}{l}80 \\
\text { 不完余:师熄 } \\
\text { 産せず }\end{array}$ \\
\hline C 2 & $\begin{array}{l}26.9 .29 \\
27.4 .10\end{array}$ & $\begin{array}{l}1^{\prime \prime} \times 61 \\
1^{\prime \prime} \times 32.5\end{array}$ & 1,070 & 1,191 & $\begin{array}{r}97 \\
121\end{array}$ & & $\begin{array}{l}1: 3.1 \\
1: 3.3\end{array}$ & 200 \\
\hline C 3 & $\begin{array}{l}27.1 .7 \\
27.4 .10\end{array}$ & $\begin{array}{c}1^{\prime \prime} \times 61 \\
\prime \prime\end{array}$ & 1,340 & 1,620 & $\begin{array}{l}300 \\
280\end{array}$ & $\begin{array}{l}800 \\
880\end{array}$ & $\begin{array}{l}1: 2.7 \\
1: 3.1\end{array}$ & 300 \\
\hline C 4 & $\begin{array}{l}27.1 .17 \\
27.4 .16\end{array}$ & $1^{\prime \prime} \times 30$ & 390 & 417 & $\begin{array}{r}100 \\
80\end{array}$ & $\begin{array}{l}710 \\
830\end{array}$ & $\begin{array}{l}1: 7.1 \\
1: 1.0\end{array}$ & $\begin{array}{l}\quad 80 \\
\text { 不完全北增 } \\
\text { 理なし }\end{array}$ \\
\hline C 5 & $\begin{array}{l}27.1 \cdot 17 \\
27.4 \cdot 10\end{array}$ & $\begin{array}{c}1 " \times 30 \\
1 "\end{array}$ & 480 & 616 & $\begin{array}{l}150 \\
136\end{array}$ & $\begin{array}{l}740 \\
650\end{array}$ & $\begin{array}{l}1: 4.9 \\
1 ; 4.8\end{array}$ & 200 \\
\hline C 6 & & & & & & & & 150 \\
\hline 計 & & & & & & & & 1,050 \\
\hline
\end{tabular}

C式斗据整によつて判明した事项は，

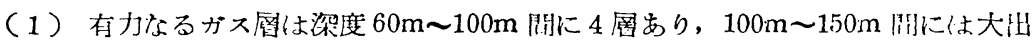
水㞗のあること。

（2）各屬の能力は揚水堭 $800 \mathrm{~m}^{3} / \mathrm{d}$ に対して約 $200 \mathrm{~m}^{3} / \mathrm{d}$ のガスを生座し得べきこ と。

（3）徉つて現有井といえどす有勃に採取するならば，6堯にて $900 \mathrm{~m}^{3} / \mathrm{d}$ は生座可 能なること。

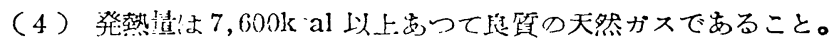

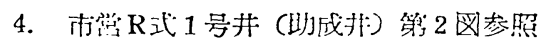

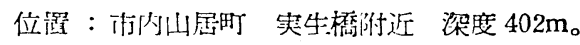

据盟目的：天然ガス調查のため。

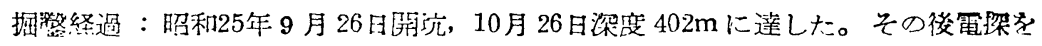

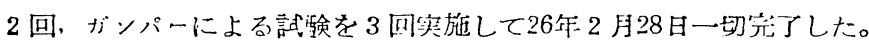

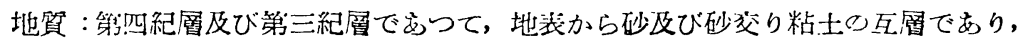




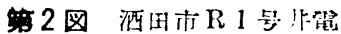
気柱妆因

简坑 9.26 .1952

海䤄上商さ $3 \mathrm{~m} 50$

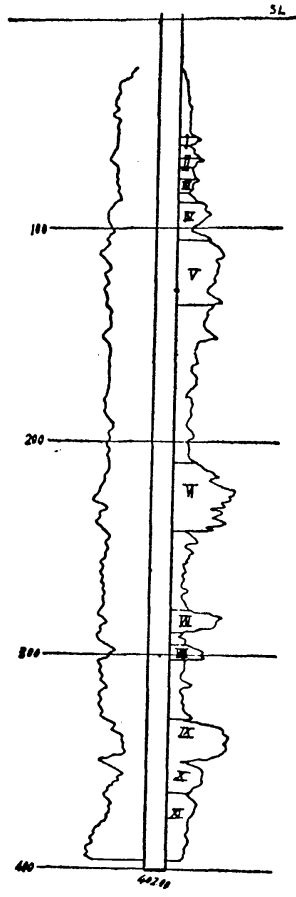

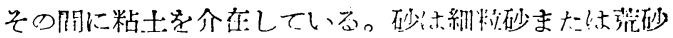

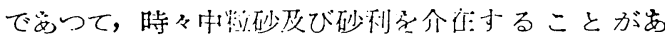

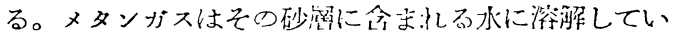
るものと思われる。

電探の結果：掘繁中は不起频的にメカニカルコア

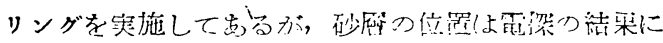
よつて初めて明睆になつた。すなわち别紙霆探図の示 すようにその位䧳保
(I) $58 \mathrm{~m} \sim 63 \mathrm{n}$
(II) $67 \mathrm{~m} \sim 73 \mathrm{~m}$
(III) $78 \mathrm{~m} \sim 85 \mathrm{~m}$
(IV) $\quad 89 \mathrm{~m} \sim 100 \mathrm{~m}$
(V) $105 \mathrm{~m} \sim 165 \mathrm{~m}$
(II) $210 \mathrm{~m} \sim 250 \mathrm{~m}$
(III) $280 \mathrm{~m} \sim 290 \mathrm{~m}$
(Vii) $297 \mathrm{~m} \sim 303 \mathrm{~m}$
(IX) $330 \mathrm{~m} \sim 350 \mathrm{~m}$
(X) $351 \mathrm{~m} \sim 364 \mathrm{~m}$

といらように明䠌となつた。すなわちC式では充分に

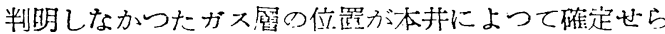
れたのである。正式凅名は地質学者が付けるとして， 一忍これらの層を上部加ら (1)………(X) と呼 称することとする。

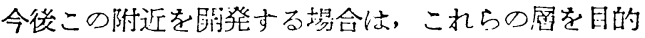

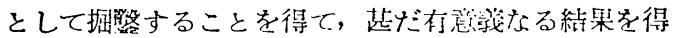
た。(第 1 図参照)

ガス試験 : アンカーパイプによる試験䒚 2 回，ガンパーによる試験を 3 回舁施している。だミ し（1）から（N）まではC式井で测定して安るので 省略している。試験の結笨は第 3 琵の通りである。

すなわち大体試験が完金と思われる（V) 及び（X) はガスがなくて汭水が多い。

(V) 及び (VII) は同時にガンパーをして同時試験を行い，その後 (VII)をプラッグ して（价）のみを試験している。その結果は（II）は非管に有望であるが（III）は ガスはなくて強力なる证水周であることが判明した。（VW）及び（IX）もまたガンパ ーによる同時試験であるが，両層ともにガスはなく多量の水屋であることが判つた。 (IV) は有然な結果を得た。

以上の通り本試験により有望な（IV)・(VI) 両層を発見したが，正確なガス量は

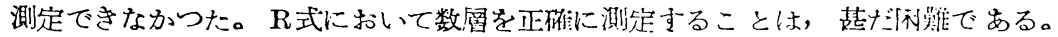

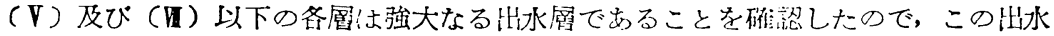
層の位罡を明確にしたことは閒発上これまた有㥕境とい5べきである。

本井によつて判明した事項を哭約すれば，

1) (I) から (X) までの梁度を確認したこと。 


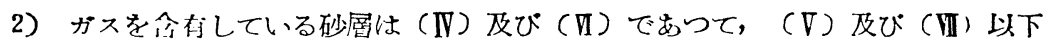

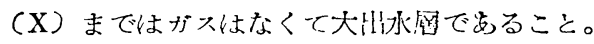

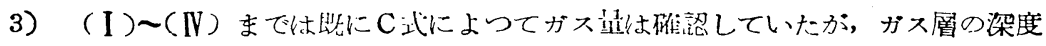
が明確ではかつたのが本井によつてこれが明らかになつた。

4）行C式井は本井の第何畨のガスを採取しているかが判明した。第 4 泰参照。

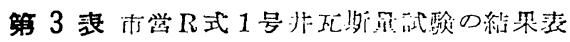

\begin{tabular}{|c|c|c|c|c|c|c|c|}
\hline 層测 & 深 & ${ }_{\mathrm{m}}$ 巳 & 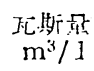 & $\mathrm{m}^{3} / \mathrm{d}$ & $\begin{array}{l}\text { 星整 } \\
\text { リフト }\end{array}$ & 化上げ & 满 \\
\hline IV & in $m$ & 11 & 100 & 1,500 & リフト & ガン登 & 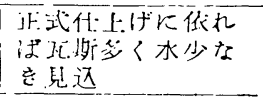 \\
\hline V & $105-155$ & 50 & 0 & 1,550 & リフト & 孔时管 & 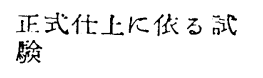 \\
\hline II & $210-250$ & 40 & 86 & 1,036 & リフト & \multirow{2}{*}{$\begin{array}{l}\text { ガンパ } \\
\text { 141発 }\end{array}$} & 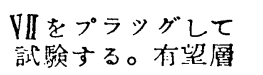 \\
\hline III & $280-290$ & 10 & 5 & $110-260$ & 自 噴 & & 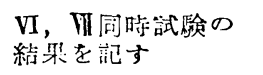 \\
\hline $\begin{array}{l}\text { VII } \\
\text { X }\end{array}$ & $\begin{array}{r}297-303 \\
330-350\end{array}$ & 20 & 0 & $50-80$ & 白 骂 & ガンパー & 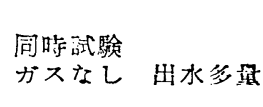 \\
\hline $\mathrm{x}$ & $351-354$ & 13 & 0 & $312-500$ & 自 喷 & 孔时管 & ガスなし 出水多咀 \\
\hline
\end{tabular}

第 4 市営 $\mathrm{R}$ 式 1 号の各層と $\mathrm{C}$ 式採取層との対比

\begin{tabular}{|c|c|c|c|c|c|}
\hline $\begin{array}{l}\mathrm{R} 1 \text { 号 } \\
\text { 井層名 }\end{array}$ & $\begin{array}{l}\text { 芯紫層 } \\
\text { 深 落 }\end{array}$ & $\begin{array}{ll}\mathrm{C} & \text { 式 } \\
\text { 抗 }\end{array}$ & 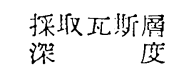 & 俑 & 考 \\
\hline I & $\underset{58-63}{m}$ & C 2 & $\begin{array}{cc}\mathrm{m} & \mathrm{m} \\
59.70-66.50\end{array}$ & & \\
\hline II & $67-73$ & $\begin{array}{l}\mathrm{C} 1 \\
\mathrm{C} 3\end{array}$ & $\begin{array}{l}68.80-78.50 \\
63.00-71.50\end{array}$ & & \\
\hline II & $78-85$ & C 6 & & & \\
\hline IV & $89-100$ & $\begin{array}{l}\mathrm{C} 4 \\
\mathrm{C} 5\end{array}$ & $\begin{array}{r}92.40-98.40 \\
93.60-100.50\end{array}$ & & \\
\hline
\end{tabular}

5. 荋石洒田 $R$ 式 1 号井

本井は石油の試掘 井として昭和21年酒 田市西北部競馬場附 近に㨄与北，梁度 1,100mに達した，油 徽はなからたけれど も天然ガスの開発に 対しては貢献与る所 が大きい。才なわち その電探四は方忿 $\mathrm{R}$ 式 1 号井と対比する を得て，ガ䃪の拉

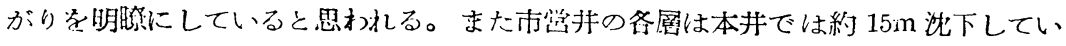




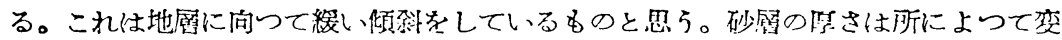

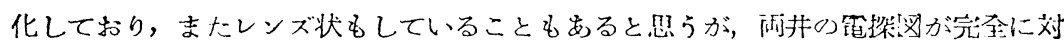

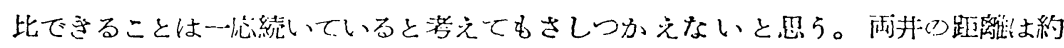
$2,500 \mathrm{~m}$ である。（第 3 畄参照）

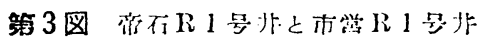
之の対比四

(雨㤢闻缡粉 $2,500 \mathrm{~m}$ ) 帝石 R. 1 朴営 R. 1

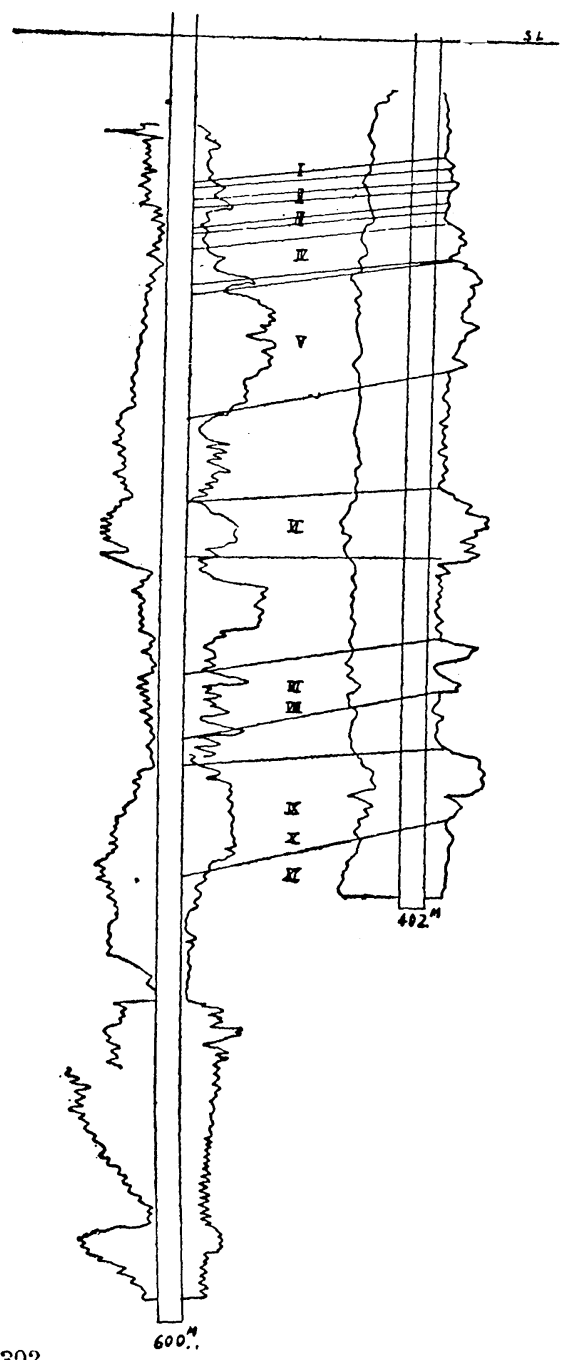

\section{IV. 試掘の結果につい ての結論}

C式井は少望のガスも検非できる

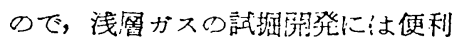
である。しかし少しく梁、捕らえと

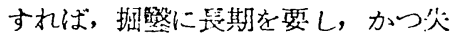
策の造除も多くなり，西探も结除で ある。R式は拥整日数も少なく，失 策の心配も少なく電探も必刑に态じ てではるあたオールコアリングあ 可能でるる。しかしガス盇の测定が 国蜼であり，少狂のガスは兒逃す恐 れが岁る。メタンガスは多くの場全 地下水に浴浶しているので，特に注 悲せざる限りR式では少娤のガスは 检䏮が困難でるる。天然ガスの試掘 にR式を使用して，相当澡くまで掘 りガスなしと判定を下した地方もあ るよ5であるが,これは(式によつ て浅層の少赑ガスを再検娸すべきで はむる东いか。 R式と C式とにはそ れぞれ臣所短所があるので，型式の 選规は大切である。本地域において は闭式を以て調查したこととなるの で，両者の欠点を補正し合5ことが できて、大体理想に近い結論を恀し 得た。すなわらこ机らの坑井から判 明したことは，それぞれ欮したが， 揭媵になとめるならば，

1）ガス層及び水㞗の梁度が明碓 となり，存空狂着は $100 \mathrm{~m}$ 以队な ること。100m 以下は $200 \mathrm{~m} 〜 250 \mathrm{~m}$ 


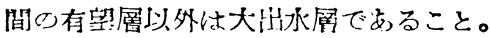

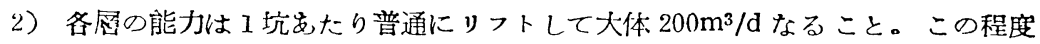

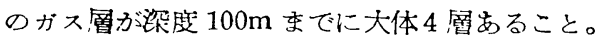

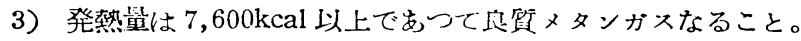

4）ガス層は酒四市附近庄内平野には公く発達していて，海岸に゙向つてやや沘下し ていること。

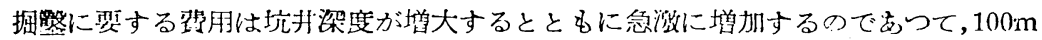
の深度で $200 \mathrm{~m}^{3} / \mathrm{d}$ を座什する坑井を 5 坑拼ることは， $500 \mathrm{~m}$ の深度で $1,000 \mathrm{n}^{3} / \mathrm{d} の$

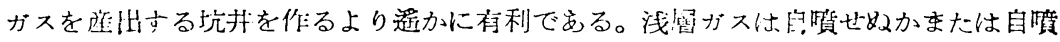

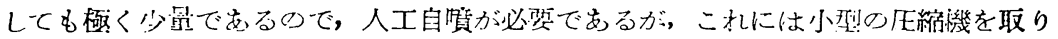
つけて简単にリフトすることによつて目的を達し得られる。

\section{V 利用價値について}

1. 生産昷限度 1 坑平均生座盕 $200 \mathrm{~m}^{3} /$ এとして, $10,000 \mathrm{~m}^{3} / \mathrm{d}$ を得るには 50 坑を

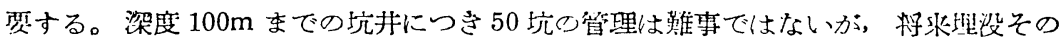
他によつて淢退することは色れないので，裐給坑井を要する。よつてこの程度のガス

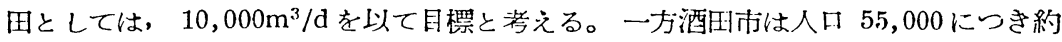
10,000豆であるから， $10,000 \mathrm{~m}^{3} / \mathrm{d}$ で充分と考之る。都市方スの普通のカロリーは約 4,000kal であり，このメタンガスのそれは $7,000 \mathrm{k}$ a 以上であるので, $10,000 \mathrm{~m}^{3} / \mathrm{d}$

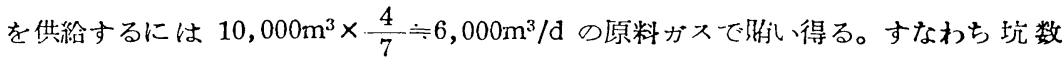
は30坑でよいこととなる。その後坑数を增加するとしても，40〜 50坑からの採取でこ の都市には充分にガスを供給し得ることとなる。

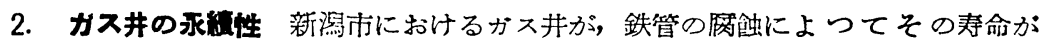

2,3 年でるるといわれているが，本地域にむいては末だ判明していない。たたこしC 式井は管成㷋 2 年半にもなるが末げその徽候はない。ガス井でも数10年氷続する例も あるので, 新潟の例を㨁もに他に適用して耉えることは古計である。相当の寿命のあ るものと考えてさしつかえないものと思われる。

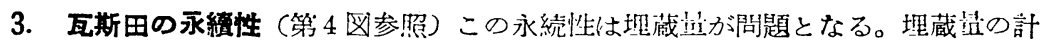
算は地筫学者に待つべきであるが，酒田市を中心として半徑 $10 \mathrm{~km}$ 内を略算しても 5

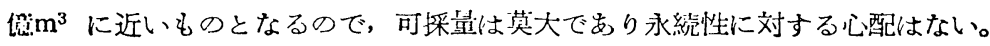

\section{VI . 事関的價值の概算}

以上の如く本地域の天然ガスの産壮望及び性筫等について概説したが，これを事業

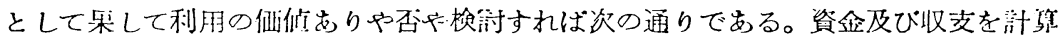

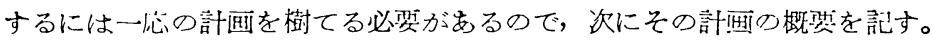

1. 計画の概要 (符 5 昤渗照) イ. 供給ガス量。ガスの供給戸数を 4,000 戸とし て，1部工坦用にも低給するとしてガス嗑 $6.000 \mathrm{~m}^{3} / \mathrm{d}$ する。 
第 4 図 酒由市を吣をとた半得 $10 \mathrm{~km}$ の円

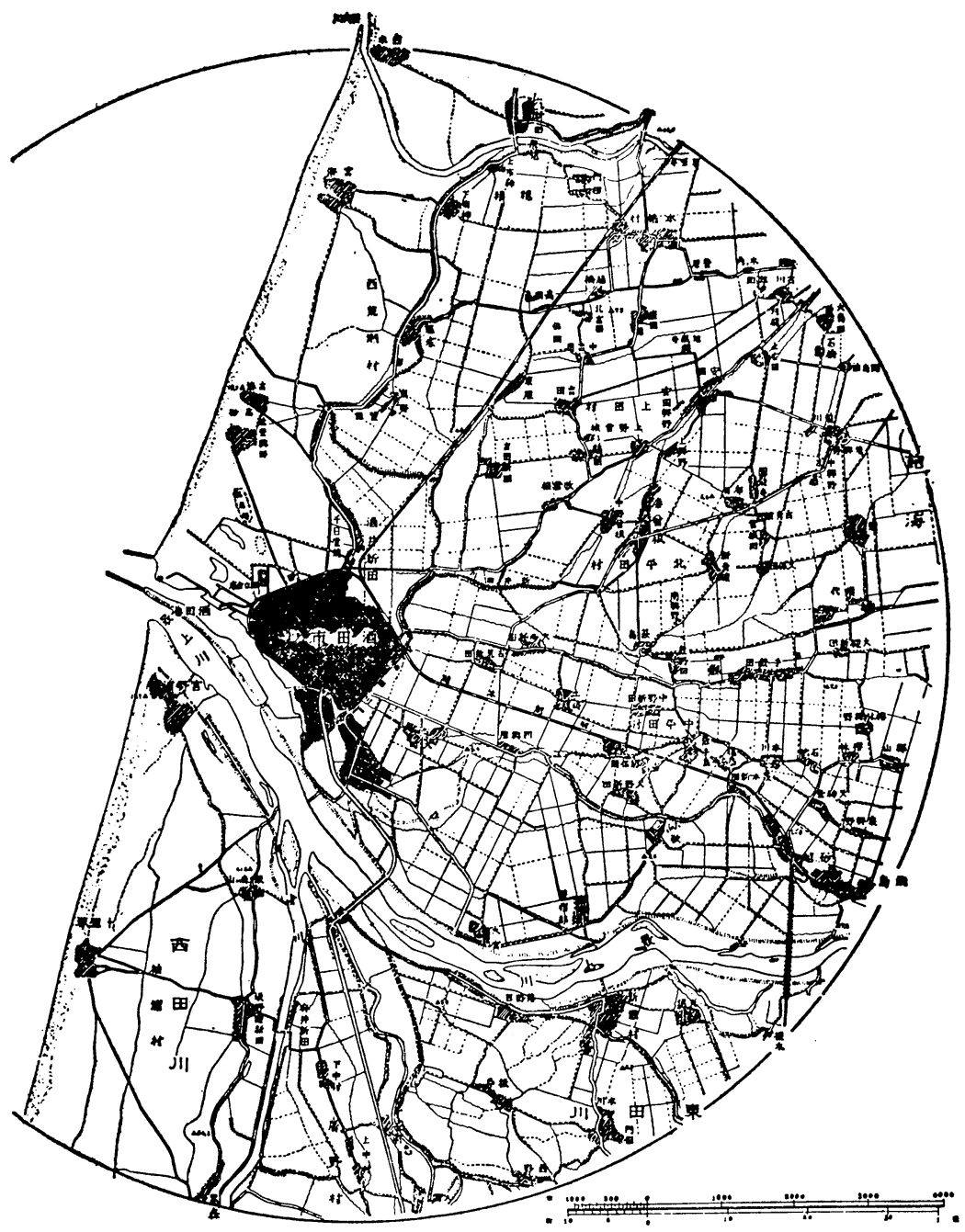

口. 探取ガス井数。 $6,000 \mathrm{~m}^{3} / \mathrm{d}$ の供給に対しては原料ガス $4,000 \mathrm{~m}^{3} / \mathrm{d}$ で充分でむる が，減退消耗等を見込えで坑井数を26坑と丁定する。

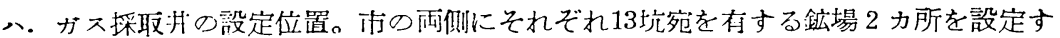

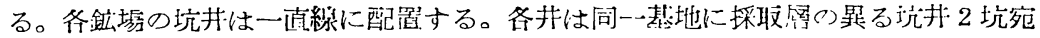

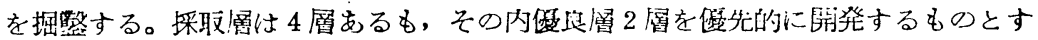




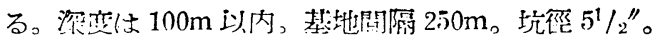

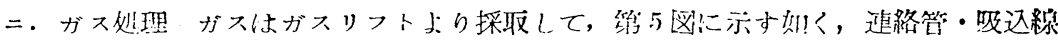
を逆じてガスタンクに入り，配紾總に送られるものと方る。

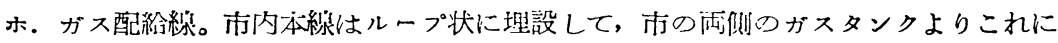
ガスを压大する。従つて一船の都市ガスに使椆する如き大径㑏の必贾がない。

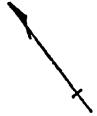

凡 例
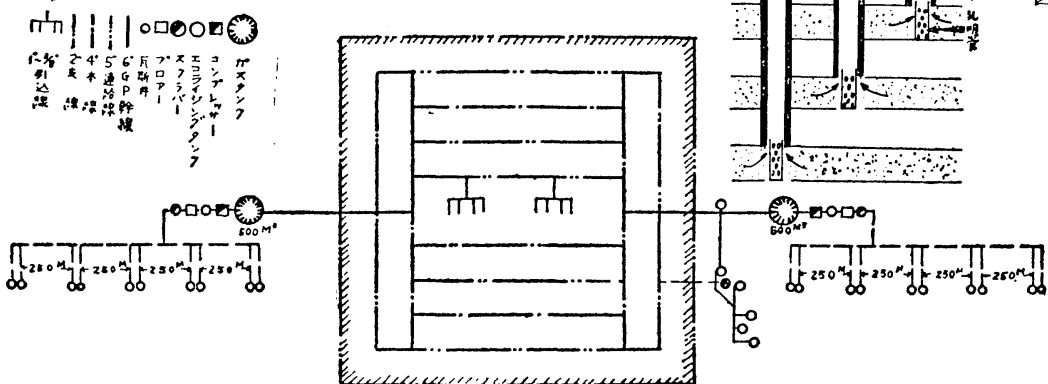

都市

钓5图天然ガスを都村ガス として抄発淇給する計画 禁想困

市

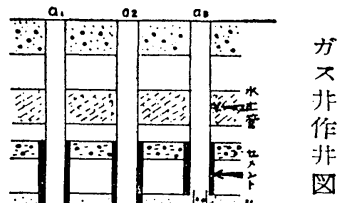

2. 建設雷の計算 以上の計画の下に建設費を詳細に計算すれば，設借全額約 6,000 万円を要することとなる。しかるに，既に約 $90 \mathrm{c} \mathrm{nI}^{3} / \mathrm{d}$ の生夝を得る 6 坑井を有する につきこのガスの販壳設備より赭手して，数年計画により逐次増設することとすれ ば，利益金の 1 部を新規設䧿費に繰り入れることにより，資本金は約 3,000 万円を以 て脽い得る計算となる。

3. 收支概算 都市ガスの公定侕格は都市によつて暴るが，附近の都市なみに計算 し，収支を概算すれば年閏の利益率は資本全の 10 割程度となる。

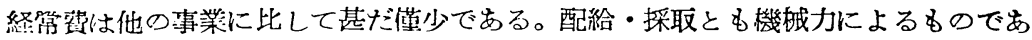
るから, 当值・坑井浚渫・配給楾の故障修理程度にて，人件費が少ない。設借は恒久

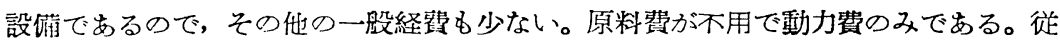
つて初期から配当も可能と思 本企 3,000 万円程度で本訫画は完成し得る計算となる。

\section{VII 結 論}

酒口市附近の天然ガスについて概説したがこれを合理的に開発し，その特性を生 かして処理するならば，都俌ガス及び工業用として採算を得る経党が可能でむり，か

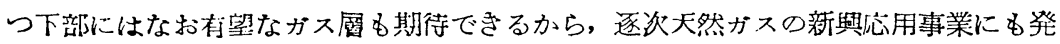


展し得るものと思われる。天然資源の泛しいわが国に扎いて, 残念ながら天然がスの 開発利月は末だ充分でない。日本の経消力恢復のために小ガス田といえども，採算の とれるものは急速に門発して有效に利用すべきものと思ら。

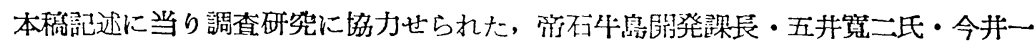
郎氏・鈴鹿堅太郎氏・諸原正太郎氏及び责重なる資料を提帒せせれた本間酒田市長・ 箱岩酒田ガス社長に謝意を表する。

\section{交 換・寄 晛 図 書 (2)}

原油関税に対する当社の意見 (蔏不石油)

世界の石油榻入関税

炤和 26 年 11 月

内外石油猫報 No. 47別删

工業教育研究集会報告

1951

対日工業教育顧問団報告書

1951

全国石油天然ガス鉣場名溜

1952

地質刑册大阪の天然ガスについて嗮鉄管は

ケーシングパイプとして用い得るか

1952

大帛の噴火 (地学雑誌特集号)

Vol. 60 No. 3.

わが国鉱工業の試験研究

1952

日本工栄技汧総覧

1951

ユネスコ国際書誌サーヴイス改良会㼁一般坏告素

1951

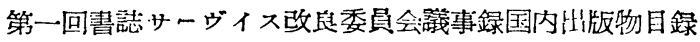

1951

知識の普遍的な索引(国際十進分類法)

1951

昭和 26 年度学協会一覧

1952

日本学術会議第 5 部集報

1951

Scientific Papers of the Collage of Ceneral Education

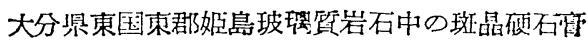

Vol. 1 No. 1

新潟罢西䣆城郡柵口地过り調查報告

地質調㮅所報告No. 126

秋田䍐花问鉱山調查報告

No. 127

群馬鉱山の鉄明攀石䙒鉄鉱铒㕅調查報告

No. 128

日本の明繁石鉣床調查報告（附宇久須の珪石鉱㕅）

No. 129

赤城火山の崩壤並に土石流

No. 130

本邦産玻琵質岩石の研究

No. 131, No. 132 , No. 133

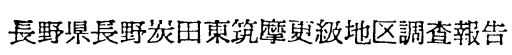

No. 134

昭和新山の地形测最報告

No. 135

地露探鉣に関する研究

No. 136

秋田冧北秋田郡大阿仁桨田比立内中利地区調查報告

No. 137

No. 138

An Orbicular Rock in Andesite from Akagi Volcano, Japan.

No. 139

常盤染田双琵地区北部地質調查報告

No. 140 